\title{
An Economic Analysis of Production of Sugarcane under various Methods of Irrigation in Sonipat District of Haryana, India
}

\author{
Dushyant Kumar ${ }^{1}$, Pukhraj Singh ${ }^{2}$, Lalit Kumar Verma ${ }^{2}$ and Nitin K. Nag ${ }^{2}$ \\ ${ }^{1}$ Department of Agricultural Economics, U.P. College Varanasi- 221003 (U.P.), India \\ ${ }^{2}$ Department of Agricultural Economics, J.V. College Baraut, Baghpat, -250611 (U.P.), India \\ *Corresponding author
}

\section{A B S T R A C T}

\section{Keywords \\ Sugarcane, \\ Productivity, Cost of cultivation, Net return, Benefit cost ratio}

\section{Article Info}

Accepted: 07 September 2019 Available Online: 10 October 2019
The present study on economic analysis of sugarcane cultivation was fulfilled with the specific objective to estimate cost and return in sugarcane cultivation was conducted in Sonipat district of Haryana state during the year 2017-18. It was selected 4 blocks randomly; namely Sonipat, Kharkhoda, Gohana, and Ganaur blocks from sonipat district were undertaken on the basis of maximum area brought under cultivation of sugarcane of haryana state. 200 farmers were selected randomly from four blocks out of which, marginal (14), small (49), medium (69) and large (68). The findings of the study envisaged that among the different irrigation methods, drip method was the highest percentage at large farm in sugarcane cultivation and found to be 78.70 percent area, which was start decreasing as farm size decreases. Drip method was not popular among marginal and small farmers. The sampled households were sugarcane growers and percentage area under sugarcane was ranging from 26.08 percent at large farms to 31.25 percent at marginal farms. The cropping intensity was also high, which varied from 105 percent at large farms to 267 percent at marginal farms. The inputs/material use in fresh sown sugarcane and ratoon crop was not as per the recommendation and initial inputs use, labour and power use were found to be less than fresh sown sugarcane. The cost of cultivation of crop under flood ratoon was $93728 \mathrm{Rs} / \mathrm{ha}$, sprinkler $97973 \mathrm{Rs} / \mathrm{ha}$ and drip $93568 \mathrm{Rs} / \mathrm{ha}$ whereas, it was found to be flood fresh sown sugarcane was $126188 \mathrm{Rs} / \mathrm{ha}$, in sprinkler $133957 \mathrm{Rs} / \mathrm{ha}$ and in drip $136043 \mathrm{Rs} / \mathrm{ha}$, respectively. This gives us variable cost incurred in ratoon crop was less than fresh sown sugarcane. The benefit cost ratio in ratoon crop of sugarcane was comparatively higher in all three methods of irrigation than that of fresh sown sugarcane; it indicates that ratoon crop has involvement of low cost of production and high net return but not have long term benefit to increase the productivity of sugarcane.

\section{Introduction}

Sugarcane is an important commercial crop of the world and the cultivation of sugarcane, in India dates back to Pre-Vedic period (2000
B.C.). India is one of the principal centers of the origin of the sugarcane. Sugarcane is grown in diversified climatic condition i.e. tropical and sub-tropical. Sugarcane cultivation and development of sugar industry 
runs parallel to the growth of human civilization and is as old as agriculture. The importance and use of sugarcane and sugar in the country's socio-economic milieu is deep rooted and immense. In the current day rural economy set up sugarcane cultivation and sugar industry has been focal point for socioeconomic development in rural areas by mobilizing rural resources, generating employment and higher income, transport and communication facilities.

Sugarcane (Saccharum spp.) is an important commercial crop in India and plays a pivotal role in agricultural and industrial economy of our country. Sugarcane is an important commercial crop of the world and more than 100 Countries produce sugar, at present Brazil, Cuba, Mexico, India and Thailand are the leading producers of sugarcane. Currently 69 per cent of the world's sugar is consumed in the country of region. Globally, sugarcane is cultivated over an area of 20.10 million hectares with a production of $1,318.10$ million tones and productivity of 65.5 tonnes per hectare. Sugarcane area and productivity differ widely from country to country. Brazil has the highest area (5.34 million hectares) while Australia has the highest productivity (85.1 tonnes per hectare) India ranks second among the sugarcane growing countries of the world in the both area and production after Brazil with an area under sugarcane cultivation of 4.94 million hectares with an average yield is 68.6 tons per hectare.

Sugarcane is heavy feeder of nutrients and requires frequent irrigation to get more productivity. The crop sown with proper spacing and stand for longer period of time. Therefore, this research work aim is to understand the private and social costs on subsidy provided for fertilizers and drip irrigation system in sugarcane cultivation and their impact on resource use efficiency. Keeping in view the above discussion of the sugarcane cultivation, the present study was an attempt to find out the cost and return of sugarcane under various method of irrigation in the study area.

\section{Materials and Methods}

The present study deals with the cost and return of sugarcane conducted in Sonipat district of Haryana state during the year 201718. It was conducted in 4 blocks; namely Sonipat, Kharkhoda, Gohana, and Ganaur blocks from Sonipat district were undertaken on the basis of maximum area brought under cultivation of sugarcane of Haryana state.

200 farmers were selected randomly from four blocks out of which, marginal (14), small (49), medium (69) and large (68) farmers based on their holding size. The primary data from the farmers was collected through personal interview method with the help of well prepared pretested schedule and questionnaire for the year 2017-18.

Collected data were tabulated according to need and purpose of study. Simple tabular analysis was made. To workout economics of Sugarcane production, different cost concept such as cost 'A', cost 'B' and cost 'C' were used.

Cost $\mathrm{A} 1=$ All actual expenses in cash and kind incurred in production by the producer. The items covered in costs on:

i) Hired human labour, ii) Hired bullock labour, iii) Owned bullock labour, iv) Home produced/purchased seed, v) Plant protection chemicals, vi) Home produced/purchased manure, vii) Fertilizers, viii) Depreciation on farm machinery, equipment and farm building, ix) Irrigation, $\mathrm{x}$ ) Land revenue, land development tax and other taxes, xi) Interest on working capital, xii) Interest on crop loan and xiii) Miscellaneous expenses. 
Cost $\mathrm{A} 2=$ Cost $\mathrm{A} 1+$ Rent paid for leased-in land

Cost $\mathrm{B} 1=$ Cost $\mathrm{A} 1+$ Interest on value of owned capital assets (excluding land)

Cost $\mathrm{B} 2=$ Cost $\mathrm{B} 1+$ Rental value of owned land (net of land revenue) and rent paid for leased-in land

Cost $\mathrm{C} 1$ = Cost B1 + Imputed value of family labour

Cost $\mathrm{C} 2=$ Cost $\mathrm{B} 2+$ Imputed vale of family labour

Cost $\mathrm{C} 3=\operatorname{Cost} \mathrm{C} 2+10$ per cent Cost $\mathrm{C} 2$

\section{Income over different cost}

Income over cost $\mathrm{A} 1=$ Output - Cost $\mathrm{A} 1$

Income over cost A2 $=$ Output - Cost $\mathrm{A} 2$

Income over cost $\mathrm{B} 1=$ Output - Cost $\mathrm{B} 1$

Income over cost $\mathrm{B} 2=$ Output - Cost B2

Income over $\operatorname{cost} \mathrm{C} 1=$ Output - Cost $\mathrm{C} 1$

Income over cost $\mathrm{C} 2=$ Output - Cost $\mathrm{C} 2$

Income over cost $\mathrm{C} 3=$ Output - Cost $\mathrm{C} 3$

\section{Results and Discussion}

Cost of cultivation of Sugarcane by method of irrigation

The cost of cultivation is a principal factor in order to pursue price policy support in terms of minimum support price declared by the government to benefit the farmers. The cost incurred on different inputs while sugarcane cultivation was varies in fresh sugarcane and ratoon sugarcane crop table 1 and 2 .
The cost of cultivation of fresh sown sugarcane the inputs/material used, human labour, power used and interest incurred shows large difference between them but the percent cost among same input, labour \& power used under three different irrigation method does not varies much. In the study, highest cost incurred in human labour i.e flood (42.83\%), sprinkler $(44.84 \%)$ and drip $(48.62 \%)$ and material used i.e., flood (27.36\%), sprinkler (27.73\%) and drip (25.44\%), irrigation methods, respectively.

The data revealed that the total fixed cost shares smaller amount i.e., flood (21.88\%), sprinkler (20.61) and drip (20.29\%) irrigation method to the total cost of cultivation where as the cost incurred in total variable cost were highest in flood (78.71\%) sprinkler (79.39\%) and drip $(79.71 \%)$ irrigated method, respectively.

Thus, the cost incurred in variable cost is higher but total cost of cultivation can be reduced by managing the resources or inputs/material, which is the cause of increased variable cost. Since, variable cost changes with level of production therefore; optimum level of inputs should be used.

The cost of cultivation for ratoon crop is lesser than fresh sown sugarcane crop. The human labour cost incurred 50 percent of total cost of sugarcane cultivation. The result reveals that the total fixed cost was higher in ratoon crop (29.45\%), sprinkler (28.18\%) \& drip (29.50\%) in flood irrigation than the fresh sown sugarcane crop.

The variable cost was in flood (70.55\%), sprinkler $(71.82 \%)$ and drip (70.50\%) irrigation method, which is lower than the fresh sown sugarcane crop. Since, variable cost changes with the levels of production, more the production higher the cost and vice versa, which interpretation that the production 
of fresh sown sugarcane is higher thus variable cost is higher where as in ratoon crop production is lower therefore the total variable cost is less than the fresh sown sugarcane crop.

\section{Economics of sugarcane cultivation}

Benefit cost ratio determine the amount of monetary gain realized by the farmers versus the amount it cost to grow sugarcane crop in the field. It was found that the amount used in inputs/material, labour and power used in fresh sown sugarcane and ratoon method under different irrigation method were varies.

Therefore, the cost of production under flood irrigation was 164.24 ₹/ha, sprinkler 152.00 ₹/ha and drip 128.84 ₹ ./ha which is higher than the ratoon crop i.e. flood 138.66 ₹ ./ha, sprinkler 126.16 ₹./ha and 97.76 ₹./ha. It was observed that cost of cultivation directly proportional to the output production level therefore, the fresh sown sugarcane has higher yield \& more cost of cultivation i.e. flood $768.30 \mathrm{q} / \mathrm{ha}$, sprinkler $881.330 \mathrm{q} / \mathrm{ha}$ and drip $1055.93 \mathrm{q} / \mathrm{ha}$ where as in ratoon the cost of cultivation is lower than the fresh sown sugarcane therefore the yield recorded as in flood $675.96 \mathrm{q} / \mathrm{ha}$, sprinkler $776.58 \mathrm{q} / \mathrm{ha}$ and drip 957.13 q/ha.

The gross return of fresh sown sugarcane was higher than the gross return of ratoon sugarcane crop but the net return of ratoon sugarcane crop is higher than the fresh sown sugarcane.

Since, net return gets by deducting all fees, expense and taxes therefore the ratoon sugarcane has higher net return because expenses and taxes i.e. cost incurred for cultivation and production is much less than the fresh sown sugarcane. Hence, monetary gain is more in ratoon crop because amount it cost to grow is less. In the study, benefit cost ratio of ratoon crop is higher 1.02 in flood, 1.22 in sprinkler and 1.86 in drip whereas in the fresh sown sugarcane benefit cost ratio is 0.70 in flood, 0.84 in sprinkler and 1.17 in drip table 3 and 4 .

This show that benefit cost ratio of ratoon sugarcane crop is higher for short period than fresh sugarcane.

The ratoon crop gives high return immediately after harvesting therefore significant important method of growing of sugarcane but not have potential to increase the productivity of the crop for long period.

\section{Break-up of total cost and income obtained over various cost of sugarcane}

The cost of cultivation also determined by the breaking-up of the total cost which standard method by CACP. The break-up of the total cost and income obtained over different cost of fresh sown sugarcane under different irrigation method is given in table 5 and 6 .

Now while calculating cost of cultivation by CACP method question arise out of 7 costs which cost is appropriate to calculate profitability (return over cost of cultivation).

In the present study, A1 and A2 cost under different method of irrigation method is same i.e., $\mathrm{A} 1=\mathrm{A} 2$ for flood irrigation method (90830.81) A1=A2 for sprinkler irrigation method (10484.76 ₹/ha) A1=A2 for drip (102825.90₹ ./ha) and return over cost A1 and A2 is also equal this is because in the study farmer does not had lease-in or lease out land.

The analyzed data reveals that the cost A1, A2 is not a appropriate cost to determine return over the cost because in these cost does not cover interest on value of owned capital assets and rent for land which would form substantial share in modern agriculture today. 
Table.1 Cost of cultivation of sugarcane fresh sown by method of irrigation (Rs./ha.)

\begin{tabular}{|c|c|c|c|c|c|c|c|}
\hline $\begin{array}{l}\text { Sr. } \\
\text { N. }\end{array}$ & Particulars & Flood & $\%$ & Sprinkler & $\%$ & Drip & $\%$ \\
\hline A. & Material cost & & & & & & \\
\hline i & Setts & 19435.94 & 15.40 & 19595.72 & 14.63 & 13783.51 & 10.13 \\
\hline ii & Fertilizer & 9454.83 & 7.49 & 11217.30 & 8.37 & 13795.35 & 10.14 \\
\hline iii & Plant Protection & 3440.08 & 2.73 & 3816.67 & 2.85 & 3947.32 & 2.90 \\
\hline \multirow[t]{2}{*}{ iv } & Irrigation charge & 2197.16 & 1.74 & 2519.34 & 1.88 & 3087.25 & 2.27 \\
\hline & Total Material cost & 34528.01 & 27.36 & 37149.03 & 27.73 & 34613.44 & 25.44 \\
\hline B & Human labour cost & & & & & & \\
\hline $\mathbf{i}$ & Family labour & 7783.13 & 6.17 & 4897.78 & 3.66 & 5642.58 & 4.15 \\
\hline \multirow[t]{2}{*}{ ii } & Hired Labour & 46261.12 & 36.66 & 55170.18 & 41.18 & 60774.35 & 44.67 \\
\hline & Total Human Labour & 54044.26 & 42.83 & 60067.96 & 44.84 & 66416.93 & 48.82 \\
\hline $\mathrm{C}$ & Power use cost & & & & & & \\
\hline $\mathbf{i}$ & Bullock Labour & 0.00 & 0.00 & 0.00 & 0.00 & 0.00 & 0.00 \\
\hline \multirow[t]{2}{*}{ ii } & Machine power & 8285.63 & 6.57 & 7278.46 & 5.43 & 5677.80 & 4.17 \\
\hline & Total power cost & 8285.63 & 6.57 & 7278.46 & 5.43 & 5677.80 & 4.17 \\
\hline \multirow[t]{2}{*}{ D } & Interest on working capital & 1726.40 & 1.37 & 1857.45 & 1.39 & 1730.67 & 1.27 \\
\hline & Total variable cost & 98584.31 & 78.12 & 106352.90 & 79.39 & 108438.83 & 79.71 \\
\hline $\mathbf{i}$ & Land revenue & 29.64 & 0.02 & 29.64 & 0.02 & 29.64 & 0.02 \\
\hline ii & Rental value of land & 24700.00 & 19.57 & 24700.00 & 18.44 & 24700.00 & 18.16 \\
\hline \multirow[t]{3}{*}{ iii } & Interest on fixed capital & 2874.46 & 2.28 & 2874.46 & 2.15 & 2874.46 & 2.11 \\
\hline & Total fixed cost & 27604.10 & 21.88 & 27604.10 & 20.61 & 27604.10 & 20.29 \\
\hline & Total Cost of cultivation & 126188.41 & 100 & 133957.00 & 100 & 136042.94 & 100 \\
\hline
\end{tabular}

Table.2 Cost of cultivation of sugarcane ratoon sown by method of irrigation (Rs./ha.)

\begin{tabular}{|c|c|c|c|c|c|c|c|}
\hline $\begin{array}{l}\text { Sr. } \\
\text { N. }\end{array}$ & Particulars & Flood & $\%$ & Sprinkler & $\%$ & Drip & $\%$ \\
\hline A. & Material cost & & & & & & \\
\hline i & Setts & 0.00 & 0.00 & 0.00 & 0.00 & 0.00 & 0.00 \\
\hline ii & Fertilizer & 8402.68 & 8.96 & 9304.12 & 9.50 & 8122.19 & 8.68 \\
\hline iii & Plant Protection & 3231.31 & 3.45 & 3094.26 & 3.16 & 2535.87 & 2.71 \\
\hline \multirow[t]{2}{*}{ iv } & Irrigation charge & 1627.79 & 1.74 & 1681.37 & 1.72 & 1721.89 & 1.84 \\
\hline & Total Material cost & 13261.78 & 14.15 & 14079.75 & 14.37 & 12379.94 & 13.23 \\
\hline B & Human labour cost & & & & & & \\
\hline $\mathbf{i}$ & Family labour & 4125.45 & 4.40 & 4023.16 & 4.11 & 2066.57 & 2.21 \\
\hline \multirow[t]{2}{*}{ ii } & Hired Labour & 43265.07 & 46.16 & 45845.55 & 46.79 & 45217.47 & 48.33 \\
\hline & Total Human Labour & 47390.52 & 50.56 & 49868.71 & 50.90 & 47284.03 & 50.53 \\
\hline $\mathbf{C}$ & Power use cost & & & & & & \\
\hline $\mathbf{i}$ & Bullock Labour & 4808.27 & 5.13 & 5716.29 & 5.83 & 5681.00 & 6.07 \\
\hline \multirow[t]{2}{*}{ ii } & Machine power & 0.00 & 0.00 & 0.00 & 0.00 & 0.00 & 0.00 \\
\hline & Total power cost & 4808.27 & 5.13 & 5716.29 & 5.83 & 5681.00 & 6.07 \\
\hline \multirow[t]{2}{*}{ D } & Interest on working capital & 663.09 & 0.71 & 703.99 & 0.72 & 619.00 & 0.66 \\
\hline & Total variable cost & 66123.65 & 70.55 & 70368.74 & 71.82 & 65963.98 & 70.50 \\
\hline $\mathbf{i}$ & Land revenue & 29.64 & 0.03 & 29.64 & 0.03 & 29.64 & 0.03 \\
\hline ii & Rental value of land & 24700.00 & 26.35 & 24700.00 & 25.21 & 24700.00 & 26.40 \\
\hline \multirow[t]{3}{*}{ iii } & Interest on fixed capital & 2874.46 & 3.07 & 2874.46 & 2.93 & 2874.46 & 3.07 \\
\hline & Total fixed cost & 27604.10 & 29.45 & 27604.10 & 28.18 & 27604.10 & 29.50 \\
\hline & Total Cost of Cultivation & 93727.75 & 100.00 & 97972.84 & 100.00 & 93568.08 & 100.00 \\
\hline
\end{tabular}


Table.3 Economics of sugarcane cultivation under fresh sown method

\begin{tabular}{|c|c|c|c|c|}
\hline Sr. N. & Particulars & Flood & Sprinkler & Drip \\
\hline $\mathbf{1 .}$ & Yield (q/ha) & 768.30 & 881.30 & $\mathbf{1 0 5 5 . 9 3}$ \\
\hline $\mathbf{2 .}$ & Cost of Cultivation (₹ /ha) & 126188.41 & 133957.00 & $\mathbf{1 3 6 0 4 2 . 9 4}$ \\
\hline 3. & Gross return (₹ /ha) & 215124.49 & 246764.49 & $\mathbf{2 9 5 6 5 9 . 0 0}$ \\
\hline $\mathbf{4 .}$ & Net Return (₹/ha) & 88936.08 & 112807.49 & $\mathbf{1 5 9 6 1 6 . 0 6}$ \\
\hline $\mathbf{5 .}$ & Cost of production (₹ $/ \mathrm{Qt})$ & 164.24 & 152.00 & $\mathbf{1 2 8 . 8 4}$ \\
\hline $\mathbf{6 .}$ & B:C Ratio & $\mathbf{0 . 7 0}$ & $\mathbf{0 . 8 4}$ & $\mathbf{1 . 1 7}$ \\
\hline
\end{tabular}

Table.4 Economics of sugarcane cultivation under ratoon sown method

\begin{tabular}{|c|c|c|c|c|}
\hline Sr. N. & Particulars & Flood & Sprinkler & Drip \\
\hline $\mathbf{1 .}$ & Yield (q/ha) & 675.96 & 776.58 & $\mathbf{9 5 7 . 1 3}$ \\
\hline $\mathbf{2 .}$ & Cost of Cultivation $(₹ / \mathrm{ha})$ & 93727.75 & 97972.84 & $\mathbf{9 3 5 6 8 . 0 8}$ \\
\hline $\mathbf{3 .}$ & Gross return (₹/ha) & 189267.87 & 217442.33 & $\mathbf{2 6 7 9 9 5 . 0 0}$ \\
\hline $\mathbf{4 .}$ & Net Return (₹ /ha) & 95540.11 & 119469.49 & $\mathbf{1 7 4 4 2 6 . 9 2}$ \\
\hline $\mathbf{5 .}$ & Cost of production (₹ $/ \mathrm{Qt})$ & 138.66 & 126.16 & $\mathbf{9 7 . 7 6}$ \\
\hline $\mathbf{6 .}$ & B:C Ratio & $\mathbf{1 . 0 2}$ & $\mathbf{1 . 2 2}$ & $\mathbf{1 . 8 6}$ \\
\hline
\end{tabular}

Table.5 Break-up of total cost and income obtained over different cost of sugarcane Fresh sown by method of irrigation (₹/ha.)

\begin{tabular}{|c|c|c|c|c|}
\hline Sr. N. & Particulars & \multicolumn{2}{|c|}{ Flood } & \multicolumn{2}{|c|}{ Sprinkler } & Drip \\
\hline $\mathbf{A}$ & & \multicolumn{2}{|c|}{ Break-up of cost } \\
\hline $\mathbf{1 .}$ & Cost A1 & 90830.81 & 101484.76 & $\mathbf{1 0 2 8 2 5 . 9 0}$ \\
\hline $\mathbf{2 .}$ & Cost A2 & 90830.81 & 101484.76 & $\mathbf{1 0 2 8 2 5 . 9 0}$ \\
\hline $\mathbf{3 .}$ & Cost B1 & 93705.27 & 104359.22 & $\mathbf{1 0 5 7 0 0 . 3 6}$ \\
\hline $\mathbf{4 .}$ & Cost B2 & 118405.27 & 129059.22 & $\mathbf{1 3 0 4 0 0 . 3 6}$ \\
\hline $\mathbf{5 .}$ & Cost C1 & 101488.41 & 109257.00 & $\mathbf{1 1 1 3 4 2 . 9 4}$ \\
\hline $\mathbf{6 .}$ & Cost C2 & 126188.41 & 133957.00 & $\mathbf{1 3 6 0 4 2 . 9 4}$ \\
\hline $\mathbf{7 .}$ & Cost C3 & 138807.25 & 147352.70 & $\mathbf{1 4 9 6 4 7 . 2 3}$ \\
\hline $\mathbf{B}$ & & Return obtained over different cost & \\
\hline $\mathbf{1 .}$ & Return over Cost A1 & 124293.67 & 145279.73 & $\mathbf{1 9 2 8 3 3 . 1 0}$ \\
\hline $\mathbf{2 .}$ & Return over Cost A2 & 124293.67 & 145279.73 & $\mathbf{1 9 2 8 3 3 . 1 0}$ \\
\hline $\mathbf{3 .}$ & Return over Cost B1 & 121419.21 & 142405.27 & $\mathbf{1 8 9 9 5 8 . 6 4}$ \\
\hline $\mathbf{4 .}$ & Return over Cost B2 & 96719.21 & 117705.27 & $\mathbf{1 6 5 2 5 8 . 6 4}$ \\
\hline $\mathbf{5 .}$ & Return over Cost C1 & 113636.08 & 137507.49 & $\mathbf{1 8 4 3 1 6 . 0 6}$ \\
\hline $\mathbf{6 .}$ & Return over Cost C2 & 88936.08 & 112807.49 & $\mathbf{1 5 9 6 1 6 . 0 6}$ \\
\hline $\mathbf{7 .}$ & Return over Cost C3 & $\mathbf{7 6 3 1 7 . 2 4}$ & $\mathbf{9 9 4 1 1 . 7 9}$ & $\mathbf{1 4 6 0 1 1 . 7 7}$ \\
\hline
\end{tabular}


Table.6 Break-up of total cost and income obtained over different cost of sugarcane ratoon sown by method of irrigation (₹/ha.)

\begin{tabular}{|c|c|c|c|c|}
\hline & Particulars & \multicolumn{1}{|c|}{ Flood } & \multicolumn{1}{c|}{ Sprinkler } & Drip \\
\hline A & & \multicolumn{2}{|c|}{ Break-up of cost } \\
\hline $\mathbf{1 .}$ & Cost A1 & 62027.84 & 66375.22 & $\mathbf{6 3 9 2 7 . 0 5}$ \\
\hline $\mathbf{2 .}$ & Cost A2 & 62027.84 & 66375.22 & $\mathbf{6 3 9 2 7 . 0 5}$ \\
\hline $\mathbf{3 .}$ & Cost B1 & 64902.30 & 69249.68 & $\mathbf{6 6 8 0 1 . 5 1}$ \\
\hline $\mathbf{4 .}$ & Cost B2 & 89602.30 & 93949.68 & $\mathbf{9 1 5 0 1 . 5 1}$ \\
\hline $\mathbf{5 .}$ & Cost C1 & 69027.75 & 73272.84 & $\mathbf{6 8 8 6 8 . 0 8}$ \\
\hline $\mathbf{6 .}$ & Cost C2 & 93727.75 & 97972.84 & $\mathbf{9 3 5 6 8 . 0 8}$ \\
\hline $\mathbf{7 .}$ & Cost C3 & 103100.53 & 107770.13 & $\mathbf{1 0 2 9 2 4 . 8 9}$ \\
\hline B & & Return obtained over different cost & \\
\hline $\mathbf{1 .}$ & Return over Cost A1 & 127240.02 & 151067.11 & $\mathbf{2 0 4 0 6 7 . 9 5}$ \\
\hline $\mathbf{2 .}$ & Return over Cost A2 & 127240.02 & 151067.11 & $\mathbf{2 0 4 0 6 7 . 9 5}$ \\
\hline $\mathbf{3 .}$ & Return over Cost B1 & 124365.56 & 148192.65 & $\mathbf{2 0 1 1 9 3 . 4 9}$ \\
\hline $\mathbf{4 .}$ & Return over Cost B2 & 99665.56 & 123492.65 & $\mathbf{1 7 6 4 9 3 . 4 9}$ \\
\hline $\mathbf{5 .}$ & Return over Cost C1 & 120240.11 & 144169.49 & $\mathbf{1 9 9 1 2 6 . 9 2}$ \\
\hline $\mathbf{6 .}$ & Return over Cost C2 & 95540.11 & 119469.49 & $\mathbf{1 7 4 4 2 6 . 9 2}$ \\
\hline $\mathbf{7 .}$ & Return over Cost C3 & $\mathbf{8 6 1 6 7 . 3 4}$ & $\mathbf{1 0 9 6 7 2 . 2 1}$ & $\mathbf{1 6 5 0 7 0 . 1 1}$ \\
\hline
\end{tabular}

The cost B1 and B2 covers the interest on value of owned capital assets and rent for land but the return over the cost $\mathrm{B} 2$ was decreased from the cost incurred in the cost B2 i.e. flood cost incurred in B2 118405.27 but the return over the cost B2is 96719.21 ₹./ha Similarly sprinkler cost B2= 129059.22 ₹./ha gets return over 117705.27 ₹./ha and in drip cost $\mathrm{B} 2=130400.36$ ₹ gets return over 165258.64 ₹./ha this shows that the rental value of owned land is very high which decrease the profitability. Moreover the cost B1 and B2 does not include the cost for performing managerial operation therefore actual profitability cannot be worked out. The cost $\mathrm{C} 2$ and $\mathrm{C} 3$ cost concept can be used to find the profitability cost $\mathrm{C} 2$ cover actual expenses in cash and kind incurred in production by owner, rent paid for leased-in land, input value of family labour and the interest on value of owned capital assets (excluding land). The $\mathrm{C} 3$ cost include all the component of cost $\mathrm{C} 2$ and adds 10 percent of the cost $\mathrm{C} 2$ on account of managerial functions performed by the farmers.
There C2 and C3 cost provided actual return over cost in the present analyzed data shows that the fresh sown sugarcane under different methods of irrigation the return over the cost C2 and C3 get decrease table 3. But, under drip irrigation method the return over the cost incurred A1, A2 and cost B1, B2 shows significant increased in return over cost A1, $\mathrm{A} 2$ and $\mathrm{B} 1, \mathrm{~B} 2$. Whereas cost $\mathrm{C} 2$ show small increase in the return over cost and return over cost C3 again get decrease due to improper management of resource in the irrigation system. Which support that the initial cost of cultivation of fresh sown is much high where as in ratoon sown crop under different irrigation the cost incurred cost $\mathrm{C} 2$ and Cost C3 is less than the fresh sown sugarcane table 4. Despite of less cost incurred in ratoon sugarcane the return over cost $\mathrm{C} 2$ under flood method is less and the return over cost C3 get decrease. Similarly under sprinkler irrigation method the return over cost was not very significant and at last not the least the drip irrigation method which is the best irrigation 
method for sugarcane crop shows highly significant increased in the profitability over the cost incurred i.e. the return over cost of $\mathrm{A} 1, \mathrm{~A} 2, \mathrm{~B} 1, \mathrm{~B} 2, \mathrm{C} 1, \mathrm{C} 2$ and $\mathrm{C} 3$ all shows high profitability than any other method of irrigation under fresh sown sugarcane method. Therefore, in the present study reveals that drip irrigation in ratoon is most demarcating method by analysis profitability over other method used in sugarcane crop.

The major findings are found as on the inputs/material use in fresh sown sugarcane and in ratoon crop in sampled farms was not as per the recommended dose and in ratoon crop the initial input, labour and power use were less than the fresh sugarcane. The number of irrigation was higher in ratoon crop than the fresh sown sugarcane under different irrigation methods. It also envisaged that initial input was less in ratoon crop therefore; the cost of cultivation of ratoon was less than fresh sown sugarcane. The total cost of cultivation of sugarcane under flood ratoon crop was 93728 ₹/ha, sprinkler 97973 ₹ /ha, and drip 93568 ₹/ha where as cost of cultivation under flood irrigation method of fresh sown sugarcane was 126188 ₹/ha, in sprinkler 133957 ₹/ha and in drip 136043 ₹ /ha. It also found that variable cost incurred in ratoon sugarcane was less than the fresh sugarcane. This depicts that variable cost changes with level of production therefore; optimum level of inputs should be used. The benefit cost ratio of ratoon crop was higher and found to be 1.02 in flood, 1.22 in sprinkler and 1.86 in drip irrigation method where as in the fresh sown sugarcane benefit cost ratio was 0.70 in flood, 0.84 in sprinkler and 1.17 in drip irrigation method. The benefit cost ratio of ratoon crop was high due to low cost of production higher net return but not have long term benefit to increase the productivity of sugarcane.

Based on outcomes, the following suggestations are hereby recommended for the welfare of sugarcane growers of the state. The ratoon crop of sugarcane is sensational between farmers as they prefer to take ratoon crop since it does not requires setts for sowing and low fertilizer applied which make farmers to believe that input cost will decrease as compared to fresh sown sugarcane. But, ratoon crop does not able to enhance the farm productivity of sugarcane in long terms. Therefore, it is recommended that farmers should not prefer more than 2 to 3 years ratoon in sugarcane cultivation. Analytical results show that drip method of irrigation in fresh sown sugarcane is profitable over cost incurred of A1, A2, B1, B2 and C3 shows high profit. Drip method of irrigation in ratoon crop is most demarcating method by profitability analysis over other method. Therefore, it should be promoted to get high return with high rate of resource efficiency and efficient use of irrigation water.

\section{References}

Gangwar, L. S. (2002). Economic analysis and resource utilization pattern under irrigated and rainfed conditions in central U. P. Agric. Econ. Res. Review. Conf. Issue. pp. 1-7

Gomatee Singh. (2013). an empirical study of economics of sugarcane cultivation and processing based farming in Uttar Pradesh. Sky Journal of Agricultural Research. 2(1):7-19.

Jadhav, A.D. (2009). Cost and revenue of sugarcane production in India: a price risk analysis. Co-operative Sugar, 40(10): 31-36.

Kishor Raj, Shukla DS, Singh TR, Yadav SR. (1997). An Enquiry into Economics of Sugar Cultivation in District Sitapur (U.P.). Cooperative Sugar. 29(32): 179-82.

Kumar D Suresh, Palanisami K. (2010) Impact of Drip Irrigation on farming system: 
evidence from southern India, Agricultural Economics Research Review, 23:265-272

Kumar, Singh, Jawla and Sachan (2014). Cost and Returns of Sugarcane Production at Different Size Groups of Farms in District Meerut (U. P.), Annals of AgriBio Research 19 (3): 561-565.

Pokharkar, V. G. and Kakad (2003). Production costs and returns of sugarcane in Maharashtra-A zonewise analysis. B. S. Cooperative Sugar $35: 119-123$.

Raj Kishor and Chaurasia, S. P. R. (2001). A study of economic analysis of sugarcane production in central plains agro-climatic zone of U. P. Cooperative Sugar 32: 715, 717-733

Saravanan, A (2016). Analysis of cost and returns of sugarcane production is Erode district of Tamil Nadu. Indian Journal of Economics and Development 4(8): 1-4.

Saravanan, K., S., Parvati (2015). An Analysis of cost and returns of sugarcane production in Krishnagiri District of Tamil Nadu. International Journal of Research 2(2): 378-384.

Saravanakumar AK, Balasubramanian R. (2016) In Sustainable sugarcane initiative (SSI) technology more profitable than conventional method of sugarcane production? An economic analysis, Agricultural Economics Research Review, 29(1):117-126

Shinde, Namadeva, Patil, B. L., Murthy, C. and Desai, N.R. M. (2009). Profitability analysis of sugarcanebased intercropping systems in Belgaum districtof Karnataka. Karnataka J. Agric. Sci. 22 : 820-823.

Singh, Archana and Srivastava, R. S. L. (2003). Growthand instability in sugarcane production in Uttar Pradesh: a regional study. Indian J. Agric.Econ. $58: 279-282$.

Singh AK, Baghel SS. (1993) Predictive models for the Area, Yield and Production of Sugarcane in Chhattisgarh and its constituent district along with the influence of Area and Yield on the Production- A different approach. Farm Science Journal, 6-9.

Thennarasu R, Banumathy V. (2011) Economics of Sugarcane Production Using Ecofriendly Technologies in Cuddalore District, Tamil Nadu, Indian Journal of Agricultural Economics, 66(1): 88-96.

Verma, A.R. (2005). Economic analysis of production and resource use efficiency of potato in Indore district of Madhya Pradesh. Indian Journal of Agricultural Economics, vol. 60. No. 3, July-Sept. Pp. 515.

\section{How to cite this article:}

Dushyant Kumar, Pukhraj Singh, Lalit Kumar Verma and Nitin K. Nag. 2019. An Economic Analysis of Production of Sugarcane under various Methods of Irrigation in Sonipat District of Haryana, India. Int.J.Curr.Microbiol.App.Sci. 8(10): 808-816. doi: https://doi.org/10.20546/ijcmas.2019.810.093 